ANNALS OF “DUNAREA DE JOS” UNIVERSITY OF GALATI
MATHEMATICS, PHYSICS, THEORETICAL MECHANICS
FASCICLE II, YEAR XII (XLIII) 2020, No. 2
DOI: $\underline{\text { https://doi.org/10.35219/ann-ugal-math-phys-mec.2020.2.01 }}$

\title{
Study of microbiological contamination level of surface water in MONITOX network areas before and after COVID-19 pandemic
}

\author{
Antoaneta Ene $e^{1,2}$, Mihaela-Aida Vasile ${ }^{2,3^{*}}$, Gabriela Bahrim ${ }^{2,3}$ \\ I "Dunarea de Jos" University of Galati, Faculty of Sciences and Environment, Department of Chemistry, \\ Physics and Environment, Galati, Romania \\ ${ }^{2}$ INPOLDE interdisciplinary research network, ReForm Multidisciplinary Platform, Dunarea de Jos University \\ of Galati, Galati, Romania \\ 3 "Dunarea de Jos" University of Galati, Faculty of Food Science and Engineering, BioAliment Platform, Galati, \\ Romania \\ *mihaela.vasile@ugal.ro
}

\begin{abstract}
The microbiological contamination of the water with faecal bacteria resulting from anthropogenic activity is an important issue for population health and the assessment of the presence of pathogenic bacteria in the water is a major concern for the protection of humans and animals. Coliform bacteria are indicators for the assessment of faecal pollution and a potential presence of pathogens, which is caused mainly by untreated wastewater. In this paper, a comparative study was carried out in 32 sampling sites of MONITOX network in two periods, June 2019 and June-July 2020, before and after COVID-19 pandemic lockdown, regarding the rate of the water microbiological contamination in Lower Danube (Calarasi/Silistra-Galati-Tulcea sectors, Danube Delta and the Black Sea coast, from the SE part of Romania, by counting of the bacteria indicators of the organic pollution (heterotrophic bacteria and total coliforms). The results demonstrate a decrease of microbiological contamination of surface water in 2020 during the COVID-19 lockdown in all the samples collected from the Black Sea coast, Danube branches, Danube-Black Sea confluence, and Danube river downwards the town of Galati.
\end{abstract}

Keywords: Danube river, Black Sea, microbiological contamination, coliforms, MONITOX , COVID-19

\section{INTRODUCTION}

Water is an indispensable component of life on Earth. All living organisms need water both as an internal environment or as a living environment. Humans use water as a technological medium, for dissolving different materials and substances, food preparation, medicines, products for veterinary or technological use, as a cooling agent for thermal processes, for washing machinery or materials, workspaces, etc. The great diversity of water uses also means a diversity of the physico-chemical, and sometimes microbiological, characteristics of different water use [1].

Microbial, chemical and radioactive pollutants existing in water bodies can cause adverse health effects when the water is destined to human consumption. In the case of chemical contaminants, due to their low amounts in water, only long-term consumption of chemical polluted water could affect human health. Instead, water containing microorganisms can give rise to real sources of disease, even at very low levels of contamination. Infected people and animals throw a large number of pathogens in their faeces, such as viruses, bacteria, protozoa or helminths. While helminths are a problem in countries with warm climates, for developed countries the other three pathogens reaching rivers and seas from domestic wastewater could raise concern. In order to ensure the protection of the ecological state of aquatic ecosystems and human health, as well as conservation of surface water resources, effective water monitoring and management systems should be established, requiring both qualitative and quantitatively analysis of water parameters. 
The increase in nutrient and pollutant loads comes from rivers, such as the Danube, from industrial and municipal wastewater sources along the coast and from discharges into the sea. Thus, the Danube provides the majority of the river inflow to the Black Sea and changes within the river basin are having an effect on the presence and evolution of nutrients and pollutants in the sea. Because a crucial issue throughout the rivers and especially in the Danube and the Black Sea basin is microbiological contamination with faecal bacteria resulted from the anthropogenic activity and the existence of large urban agglomerations, the assessment of the presence of pathogenic bacteria in the water is a major concern for the protection of human and animal health $[1,2]$.

Coliform bacteria are indicators for the assessment of faecal pollution and a potential presence of pathogens, which is caused mainly of untreated wastewater. Regular monitoring of coastal waters is strongly recommended for the prevention of water-borne diseases, including testing for total and faecal coliforms [3-6]. The group of bacteria called total coliform bacteria is widespread in nature. All kinds of bacteria belonging to the group of total coliform bacteria exist primarily in human faeces, but they could be encountered in animal manure and soil. The presence of coliform bacteria is one of the most prevalent problems in terms of public health in aquatic ecosystems over the world [7]. Since the 1920 's, total coliforms and faecal coliforms have been used as microbiological indicators in determining the microbiological quality of water. The presence of coliform and heterotrophic bacteria in high concentrations in water indicates the human impact on water contamination $[4,8,9]$.

In this study, we aimed to evaluate the level of the microbiological contamination of the Danube and the Black Sea water in the BSB27 MONITOX project target sites, from the SE part of Romania (Fig.1) and compare the level of pollution in two monitoring periods - before and after COVID-19 pandemic lockdown in spring 2020 - based on the counting of the bacteria indicators of the organic pollution (heterotrophic bacteria and total coliforms).

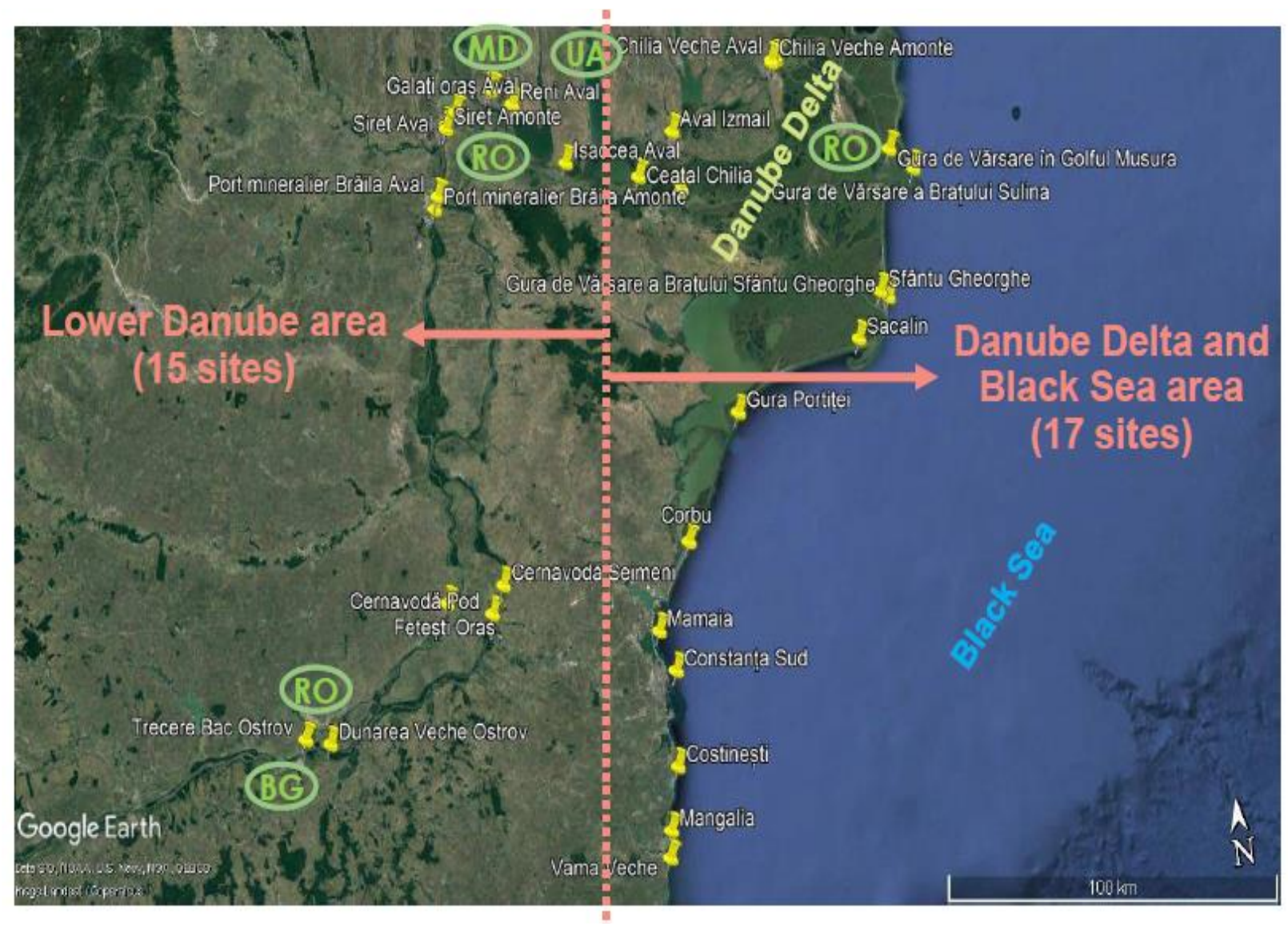

Fig. 1. Sampling points of surface water from MONITOX network areas in Romania and border regions $R O-B G, R O-M D$ and $R O-U A$ 


\subsection{STUDY AREA}

\section{EXPERIMENTAL}

Water samples were collected in 32 different sites from two parts of the Romanian MONITOX Network area (Fig.1) in June 2019 and June-July 2020, before and after COVID-19 pandemic lockdown, respectively, as follows:

1) the Lower Danube River area, sector Ostrov - Isaccea, with 15 different sites (laboratory codes 115): 1- Ostrov ferryboat station (near Calarasi/Silistra); 2-Old Danube Ostrov; 3-Cernavoda bridge; 4-Cernavoda Seimeni; 5-Fetesti; 6 - downstream Braila ore port; 7- upstream Braila ore port; 8-upstream Siret river confluence with the Danube; 9 - downstream Siret river confluence with the Danube; 10 - downstream Galati ore port; 11- downstream Galati town; 12-upstream Prut river confluence with the Danube, Giurgiulesti; 13-downstream Prut river confluence with the Danube; 14-downstream Reni; 15-downstream Isaccea (Fig. 1 - left side) and

2) the Danube Delta-Black Sea area with 17 different sites (laboratory codes 16-32): 16-Ceatal Chilia; 17-downstream Izmail; 18-downstream Chilia Veche; 19-upstream Chilia Veche; 20Musura mouth; 21-Ceatal Sfantu Gheorghe; 22-Upstream Sfantu Gheorghe; 23-Mouth of the Sulina branch; 24-Mouth of the Sfantu Gheorghe branch - downstream; 25-Sacalin; 26-Gura Portitei, Black Sea; 27-Corbu, Black Sea; 28-Mamaia; 29-Constanta South; 30-Costinesti; 31Mangalia; 32-Vama Veche (Fig. 1 - right side).

\subsection{MICROBIOLOGICAL ANALYSES}

The analyzed microbiological indicators were heterotrophic bacteria and total coliforms.

The assay for heterotrophic bacteria count was performed by cultivation on plate count agar medium (pour plate method), at $37^{\circ} \mathrm{C}$, for $48 \mathrm{~h}$. The contamination level was expressed as Colony Forming Units/mL (CFU/mL).

The coliform bacteria were analyzed according to ISO 4831-92 Standard (Most Probable Number Technique), by cultivation in specific medium with lactose, for $48 \mathrm{~h}$, at $37^{\circ} \mathrm{C}$, and the contamination level was expressed as Most Probable Number (MPN) of coliforms, CFU/100 mL. This method involved two tests - the presumptive test and the confirmation test. For the presumptive test, it was used meat broth with lactose and Durham tubes. The confirmation test was performed with Brilliant Green Bile 2\% broth with Durham tubes. After incubation, the presence of the gas in Durham tubes and the change color of the medium from green in yellow indicated the growth of coliform bacteria $[3,10]$.

\section{RESULTS AND DISCUSSION}

The appropriateness for utilization of total coliforms as an indicator of water faecal contamination depends on the extent to which the found bacteria species are faecal and human in origin. Four indicators (faecal coliform, Pseudomonas aeruginosa, Escherichia coli, and coliphage) could be used to determine the level of faecal pollution [6]. However, testing for all disease-causing organisms is extremely time consuming and expensive, thus we tested coliforms to give an indication of the presence of pathogens so that corrective action can be taken. Total coliform bacteria is a standard to determine the bacterial safety of the water. The levels of heterotrophic bacteria are generally correlated with contamination by organic matter.

Due to the fact that coliforms and faecal streptococci are commonly found in human and animal faeces, these groups of microorganisms are used in water monitoring programs as indicators of possible contamination of sewage effluents because these groups of microorganisms are commonly found in human and animal faeces. Although they are generally not harmful themselves, they represent useful indicators of the existence of disease-causing bacteria, viruses, and protozoa which also live in human and animal digestive systems. Thus, their levels detected in water bodies reflect the presence of pathogenic microorganisms and the health risk related to bathing or eating fish and seafood [11]. 
In this work, the total coliform bacteria and the heterotrophic bacteria were investigated, before and after COVID -19 pandemic, as main bacteriological indicators for the microbiological quality of water sampled from the Danube River (Romania) area in 15 different sites in the sector Ostrov - Isaccea, and from the Danube Delta-Black Sea (Romania) area in 17 different sites. The results are presented in Figs. 2 and 3 for total coliforms (in CFU/100 mL) and Figs. 4 and 5 for heterotrophic bacteria (in $\mathrm{CFU} / \mathrm{mL}$ ).

According to class limit values for bacteriological determinants [9], the Danube River and the Danube Delta-Black Sea water samples were characterized by a moderate number of coliforms bacteria. Exception made some sampling sites located in several sectors of the lower part of the Danube river, upwards Galati town, Romania, where the bacteriological load is critical.

For the water samples collected from the two studied areas, before the COVID pandemic (June 2019), the coliform bacteria have been identified in all the water samples (Figs. 2, 3) and their numbers varied between $130 \mathrm{CFU} / 100 \mathrm{~mL}$ (site no.2 - Old Danube Ostrov) and $250000 \mathrm{CFU} / 100 \mathrm{~mL}$ (site no.1 - Ostrov ferryboat station (near Calarasi/Silistra)) in the Lower Danube sector (Fig. 2) and between $10 \mathrm{CFU} / 100 \mathrm{~mL}$ (site no.17 - downstream Izmail) and $70000 \mathrm{CFU} / 100 \mathrm{~mL}$ (site no.24 Mouth of the Sfantu Gheorghe branch - downstream) in the Danube Delta-Black Sea area (Fig. 3).

After the COVID pandemic lockdown (June-July 2020), total coliforms level varied between 250 CFU/mL (site no.12 - upstream Prut river confluence with Danube, Giurgiulesti) and 70000 CFU/100 mL (sites nos. 1 - Ostrov ferryboat station (near Calarasi/Silistra) and 9 - downstream Siret river confluence with the Danube) in the Lower Danube sector (Fig. 2) and between $10 \mathrm{CFU} / 100 \mathrm{~mL}$ (site no.17 - downstream Izmail) and 7000 CFU/100 mL (site no.18 - downstream Chilia Veche) in the Danube Delta-Black Sea area (Fig. 3).

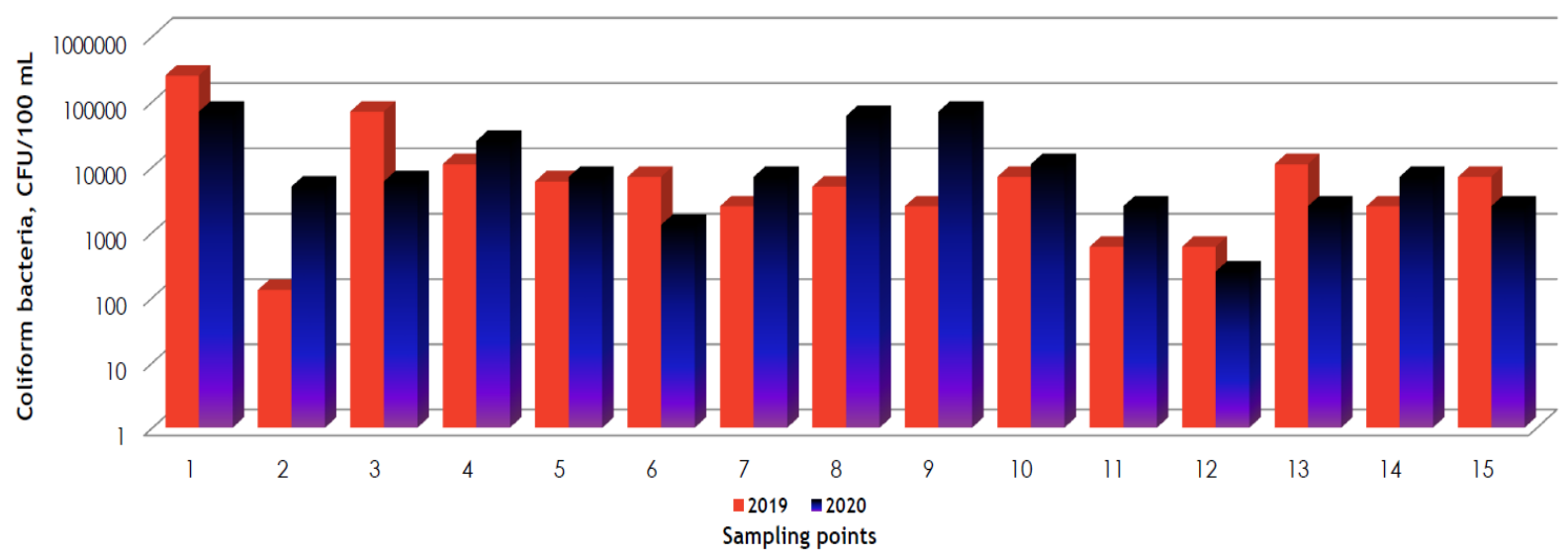

Fig. 2. The variation of the number of total coliforms before (2019) and after (2020) COVID-19 pandemic in water samples from the Danube River area, expressed in CFU/100 mL.

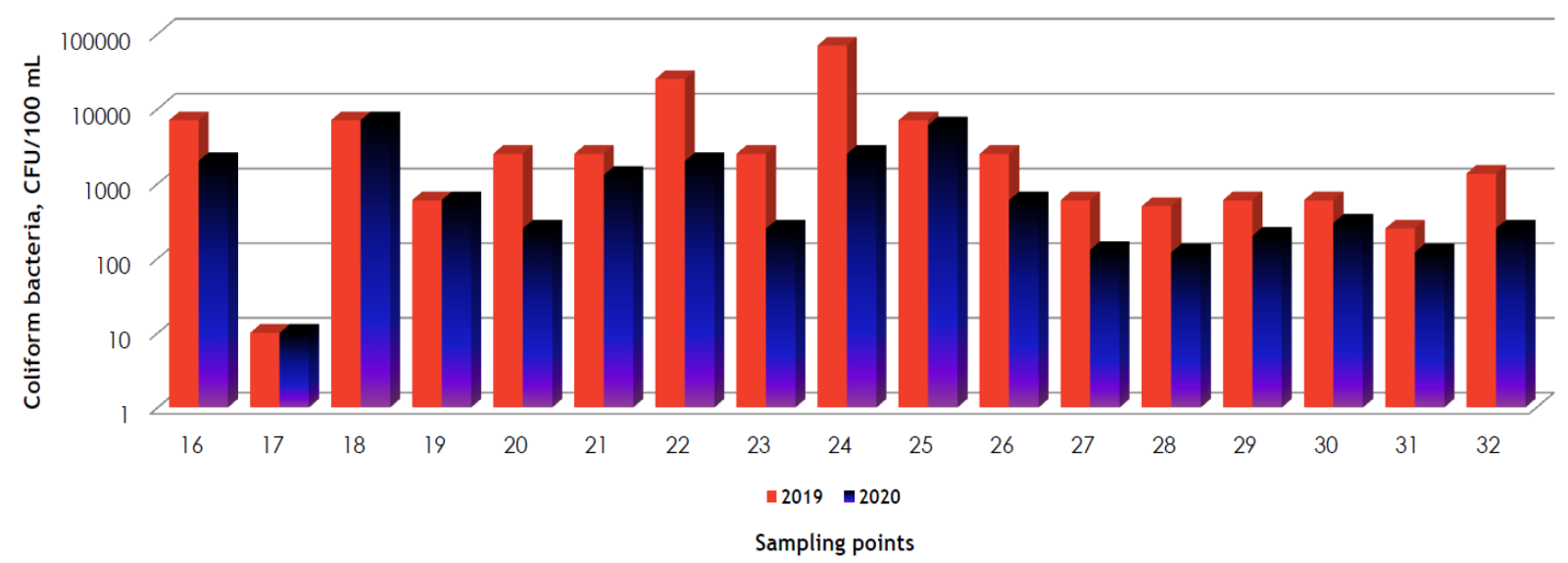

Fig. 3. The variation of the number of total coliforms before (2019) and after (2020) COVID-19 pandemic in water samples from the Black Sea area, expressed in CFU/100 mL. 
The heterotrophic bacteria serve as an indicator in the evaluation of the water quality with respect to the decomposing activity. The number of heterotrophic bacteria in the analyzed water ranged from $155 \mathrm{CFU} / \mathrm{mL}$ (site no. 6 - downstream Braila ore port) to $6080 \mathrm{CFU} / \mathrm{mL}$ (site no. 8 upstream Siret river confluence with the Danube) in the Lower Danube sector (Fig. 4) and from 111 $\mathrm{CFU} / \mathrm{mL}$ (site no.31 - Mangalia) to $17000 \mathrm{CFU} / \mathrm{mL}$ (site no.24 - Mouth of the Sfantu Gheorghe branch - downstream) in the Danube Delta-Black Sea area (Fig. 5). After the COVID pandemic lockdown (June-July 2020), heterotrophic bacteria level varied between $110 \mathrm{CFU} / \mathrm{mL}$ (site no.7 upstream Braila ore port) and $12000 \mathrm{CFU} / \mathrm{mL}$ (site no. 2 - Old Danube Ostrov) in the Lower Danube sector (Fig. 4) and between $41 \mathrm{CFU} / \mathrm{mL}$ (site no.31 - Mangalia) to $2750 \mathrm{CFU} / \mathrm{mL}$ (site no.18 downstream Chilia Veche) in the Danube Delta-Black Sea area (Fig. 5).

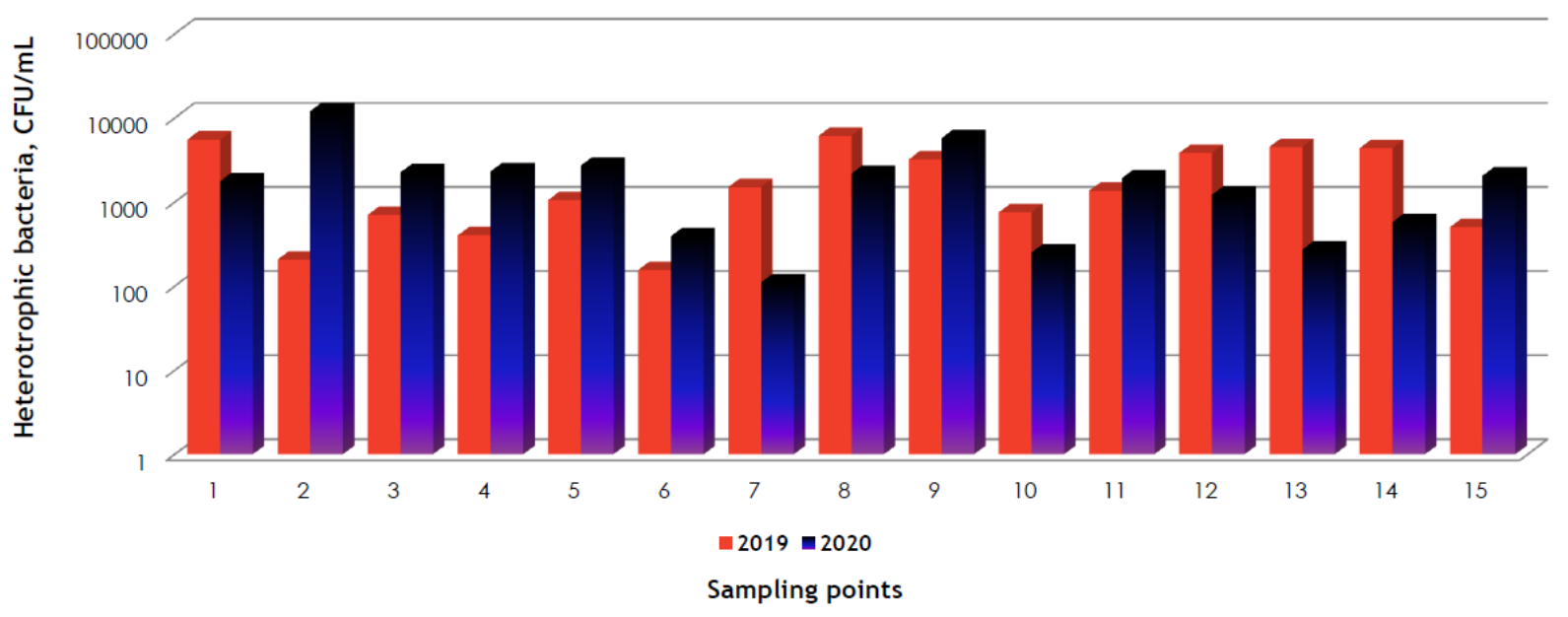

Fig. 4. The variation of the number of heterotrophic before (2019) and after (2020) COVID-19 pandemic in water samples from the Danube River area, expressed in CFU/mL.

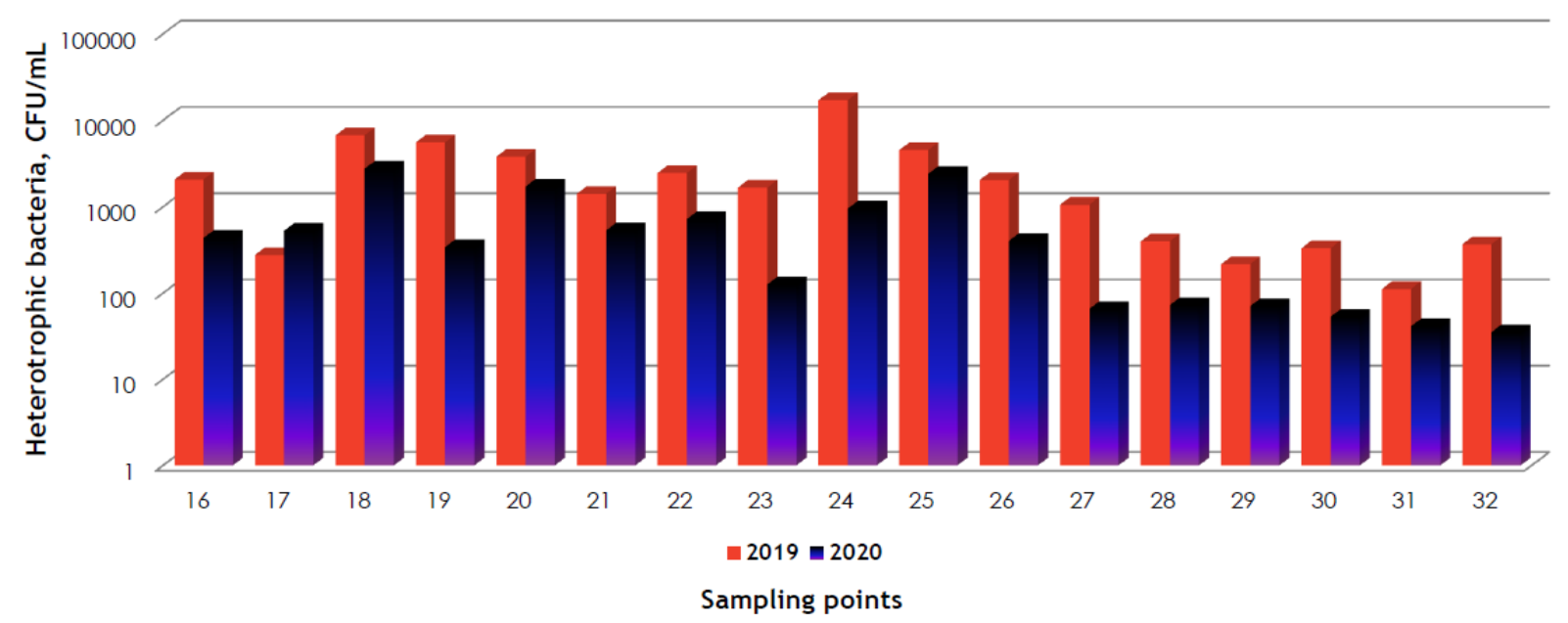

Fig. 5. The variation of the number of heterotrophic bacteria before (2019) and after (2020) COVID19 pandemic in water samples from the Danube Delta-Black Sea area, expressed in CFU/mL.

After the COVID pandemic (June-July 2020), for most of the sampling stations in the Danube Delta and Black Sea area (Romania), the number of bacteria in water decreased by a factor ranging between 1.2 and 28 for total coliforms (Fig. 3) and between 1.9 and 17.9 for heterotrophic bacteria (Fig. 5) (calculations not shown).

In the Danube river area, for approximately $50 \%$ of sampling points, the water samples showed a decrease between 2.4 and 11.7 for total coliforms and between 3.1 and 16.7 for heterotrophic bacteria (Figs. 2 and 4 ). 
Concerns about the microbiological contamination of the Danube river water have existed for many years. A crucial problem in the entire Danube river basin is the microbiological contamination due to faecal pollution. In the investigated period between mid-August and the end of September in 2001 and 2007, it was established an integrative picture of faecal pollution in the Danube river basin, through statistical analysis based on a variety of variables. A decrease in microbiological pollution was observed in the upper and lower part of the Danube, and in the middle part, an increase in this type of pollution [8]. Recent researches presented a new approach for the analysis of faecal pollution of river waters in order to achieve a clear interpretation of the patterns of faecal contamination of these waters. The new concept was demonstrated on the Danube River and in its associated water area downstream of Vienna [12]. The data set used in that concept was obtained over 3 years, with a number of 317 samples from 10 sites. The novelty of the approach was the comparison of the concentrations of faecal bacteria with the connectivity of the river in order to allow the definition of the sites with the dominant influence in pollution compared to the weak pollution in the Danube River. This approach is useful by clearly delimiting the type of faecal pollution of water, respectively autochthonous, allochthonous, human or animal faecal pollution.

The results of our research are comparable to those recently published in the literature. The decrease in the number of coliforms in river water during the COVID-19 pandemic is reported in other papers. Thus, the decrease of coliforms number during the COVID-19 pandemic was confirmed in the water of the river Ganges along the city of Kolkata, India, in two sampling points: in Babughat there was a decrease of $20.33 \%$ and in the area of Hooghly Bridge, a decrease of $19.59 \%$ [13]. The water quality in the industrial coastal town of Tuticorin in southern India was studied based on the chemical and microbiological parameters, before and during COVID-19 pandemic (between March 25 and May 30,2020 ). The results proved a decrease of more than $50 \%, \mathrm{NO}_{3}$, total coliforms and faecal coliforms due to a lower amount of organic waste from wastewater as a result of the reduction of activity in the fishing industry [14].

Compared to data from recently published researches $[13,14]$, the decreasing tendency of the coliform bacterial load in the majority of target locations in the Danube and the Black Sea region demonstrated in our preliminary study, might be due to the reduction of the functioning of industrial units, tourism and traffic movements during the COVID-19 pandemic, including border regions ROBG, RO-MD and RO-UA. More research of factors which could influence the annual variations of bacteriological load in the Danube and the Black Sea water is needed [15].

\section{CONCLUSIONS}

The microbiological contamination of the water in the Black Sea basin is a direct effect of both natural and anthropogenic causes. Rivers may be potential pathways for microbiological contamination of the surrounding environment and seas.

The results obtained by us demonstrate a decrease of microbiological contamination of surface water in 2020 during the COVID-19 lockdown in all the samples collected from Black Sea coast, Danube branches, Danube-Black Sea confluence, and Danube river downwards Galati town. Overall, the assessment of microbial water quality is necessary to evaluate the significance of increasing anthropogenic impact on the Danube River, Danube Delta and the Black Sea. According to international classifications for bathing waters, the water samples were mostly characterized by a moderate number of coliforms bacteria. Exception made some sampling sites located in several sectors of the lower part of the Danube river, upwards the town of Galati, Romania, for which critical values were encountered.

Further research will be published on the imprint of nationwide COVID-19 epidemic lockdown on surface water quality in transboundary Danube-Black Sea regions, based on the results obtained for the chemical and biological parameters in the thirty-two target locations of MONITOX network. Application of multivariate statistical analysis techniques will help us to elucidate the anthropogenic or natural sources that impacted the Danube water quality during the COVID-19 pandemic lockdown compared to that recorded in the pre-lockdown period. 
Acknowledgements: The authors would like to thank the funding of project BSB27-MONITOX (2018-2021), Joint Operational Programme Black Sea Basin 2014-2020.

\section{References}

1. Ungureanu C., Ifrim G., Ene A., Bahrim G., Turturica M., Chemical and microbiological analysis of water quality from Lower Danube region, Annals Univ. Dunarea de Jos Galati, Fasc. II - Mathematics, Physics, Theoretical Mechanics, 37(2) (2014), 209-215.

2. Janelidze N., Jaiani E., Lashkhi N., Tskhvediani A., Kokashvili T., Gvarishvili T., Jgenti D., Mikashavidze E., Diasamidze R., Narodny S., Obiso R., Whitehouse C.A., Huq A., Tediashvili M., Microbial water quality of the Georgian coastal zone of the Black Sea, Marine Pollution Bulletin 62 (2011) 573-580.

3. American Public Health Association (APHA), Standard Methods for the Examination of Water and Wastewater. 22nd ed. (2012) American Public Health Association, Washington D.C.

4. Pall E., Niculae M., Kiss T., Sandru C.D., SpInu M., Human impact on the microbiological water quality of the rivers, Journal of Medical Microbiology, 62 (2013) 1635-1640, DOI 10.1099/jmm.0.055749-0055749

5. Sanders B.F., Arega F., Sutula M., Modeling the dry-weather tidal cycling of faecal indicator bacteria in surface waters of an intertidal wetland. Water Research 39 (14) (2005) 3394-3408.

6. Dutka B. J., Marsalek J., Urban Impacts on River Shoreline Microbiological Pollution, J. Great Lakes Res. 19(4) (1993) 665-674.

7. Berber I., Avşar C., Investigating Some Microbial Pollution Parameters of Seawater and Mussels (Mytilus galloprovincialis, Lamarck 1819) of Sinop Black Sea Coastal Zone, Turkey Sains Malaysiana 43(12) (2014) 1835-1842.

8. Kirschner A.K..T., Kavka G.G., Velimirov B., Mach R.L., Sommer R. Farnleitner A.H., Microbiological water quality along the Danube River: integrating data from two whole-river surveys and a transnational monitoring network. Water Research 43 (2009) 3673-3684.

9. Kavka G.G., Kasimir G.D., Farnleitner A.H., Microbiological Water Quality of the River Danube (Km 2581 - Km 15): Longitudinal Variation of Pollution as Determined by Standard Parameters, Austrian Committee Danube Research/IAD, Vienna, Austria (2006), pp. 415-421.

10. WHO, Guidelines for Drinking water Quality $4^{\text {th }}$ Ed., ISBN 978-92-4-154995-0, World Health Organization Geneva, 7 Microbial aspects, (2017) 117-153.

11. Wheeler A.L., Hartel P.G., Godfrey D.G., Hill J.L., Segars W.I., Potential of Enterococcus faecalis as a human faecal indicator for microbial source tracking. Journal of Environmental Quality 31 (2002) 1286-1293.

12. Frick C., Vierheilig J., Nadiotis-Tsaka T., Ixenmaier S., Linke R., Reischer G. H., Komma J., Kirschner A. K.T., Mach R. L., Savio D., Seidl D., Blaschke A. P., Sommer R., Derx J., Farnleitner A. H. Elucidating faecal pollution patterns in alluvial water resources by linking standard faecal indicator bacteria to river connectivity and genetic microbial source tracking, Water Research 184 (2020) 116132, 1-12.

13. Mukherjee P., Pramanick P., Zaman S., Mitra A. Eco-restoration of River Ganga water quality during COVID-19 lockdown period using Total Coliform (TC) as proxy, NUJS Journal of Regulatory Studies, Special Edition (2020) 67-74.

14. Selvam S., Jesuraja K., Venkatramanan S., Chung S.Y., Roy P.D., Muthukumar P., Kumar M., Imprints of pandemic lockdown on subsurface water quality in the coastal industrial city of Tuticorin, South India: A revival perspective, Science of the Total Environment 738 (2020) 139848, 3-7.

15. Kirschner A.K.T., Reischer G.H., Jakwerth S., Savio D., Ixenmaier S., Toth E., Sommer R., Mach R.L., Linke R., Eiler A., Kolarevic S., Farnleitner A.H., Multiparametric monitoring of microbial faecal pollution reveals the dominance of human contamination along the whole Danube River, Water Research 124 (2017) 543-555. 